\title{
Hydroxychloroquine Use in Patients With COVID-19: A Brief Perspective on Current Clinical Trials
}

\author{
Alaa A. Abd-Elsayed, MD, MPH, ${ }^{1}$ David Hao, MD, ${ }^{2}$ Robert Chu, BA, ${ }^{3}$ Ivan Urits, MD, ${ }^{4}$ Omar Viswanath, MD, ${ }^{5}$ \\ Vwaire Orhurhu, MD, $\mathrm{MPH}^{2}$ \\ ${ }^{1}$ Department of Anesthesiology, Division of Pain Medicine, University of Wisconsin School of Medicine and Public Health, Madison, WI \\ ${ }^{2}$ Department of Anesthesia, Critical Care and Pain Medicine, Massachusetts General Hospital, Harvard Medical School, Boston, MA ${ }^{3}$ Johns \\ Hopkins School of Medicine, Baltimore, MD ${ }^{4}$ Department of Anesthesia, Critical Care and Pain Medicine, Beth Israel Deaconess Medical \\ Center, Harvard Medical School, Boston, MA ${ }^{5}$ Department of Anesthesiology, Creighton University School of Medicine, Omaha, NE; Valley \\ Anesthesiology and Pain Consultants, Envision Physician Services, Phoenix, AZ; and Department of Anesthesiology, University of Arizona \\ College of Medicine-Phoenix, Phoenix, AZ
}

\section{INTRODUCTION}

Severe acute respiratory syndrome coronavirus 2 (SARSCoV-2), the virus responsible for coronavirus disease 2019 (COVID-19), remains elusive and nonresponsive to medication management. As the medical community forges ahead with exploring therapies, we must understand and learn from the clinical trials that have investigated the use of hydroxychloroquine (HCQ) and chloroquine (CQ) in patients with COVID-19.

Initial interest in the use of $\mathrm{HCQ}$ was triggered by a small nonrandomized study that has since received heavy criticism for both its statistical methods and potential conflicts of interest, as the journal editor-in-chief was included as an author. ${ }^{1-3}$ As a result of this controversial study and the subsequent widespread discussion of $\mathrm{HCQ}$ in the lay media, rigorous study of HCQ and CQ use in patients with COVID-19 was needed.

\section{OVERVIEW OF CLINICAL TRIALS}

Since the first case of COVID-19 was reported in December 2019, a total of 10 randomized clinical trials (RCTs) have investigated treatment with HCQ (Table). ${ }^{4-13}$ These clinical trials included patients at multiple stages of severity, including asymptomatic without hospitalization, symptomatic with mild or moderate illness, and symptomatic with severe illness. From the outset, the external validity of studies investigating HCQ use in patients with COVID-19 has been challenged by heterogeneous methods of patient selection that have ranged from asymptomatic individuals with an identified exposure to hospitalized patients with clinical suspicion to positive reverse transcriptase-polymerase chain reaction (RT-PCR) with chest computed tomography (CT) evidence of pneumonia. In one RCT, methods of diagnostic confirmation of COVID-19 were not even specified. ${ }^{4}$ Drawing conclusions from highly variable clinical and laboratory diagnostic methodologies is fraught with potential error. Irrespective of the ultimate conclusions of the studies, we start first with the appreciation that not all studies are created equal. To add to the variability of the trials, the intervention and treatment dosing fluctuated substantially from center to center. Although the majority of studies elected to compare $\mathrm{HCQ}$ to standard of care, the dose and duration of HCQ treatment in the experimental group and what constituted standard of care varied significantly among studies. To add perspective, only 2 trials had an identical intervention regimen of $400 \mathrm{mg} \mathrm{HCQ}$ for a cumulative 5 days. ${ }^{4,5}$ With these caveats in mind, we turn to the outcomes of these trials.

The largest study as of October $2020(n=821)$ observed development of positive molecular assay or COVID-19related symptoms in previously asymptomatic individuals with exposure to confirmed COVID-19. ${ }^{6}$ No significant difference was observed between the $\mathrm{HCQ}$ treatment group (one-time 800-mg dose followed by $600 \mathrm{mg} /$ day for 5 days) and placebo group in the development of COVID-19, with the notable caveat that the majority of participants had limited access to COVID-19 testing.

An open-label RCT among hospitalized patients with COVID-19 used a regimen of HCQ (400 mg twice daily) plus standard of care or HCQ with azithromycin (500 mg daily) plus standard of care. Results indicated no significant differences in the primary outcome of clinical status at day 15 or any secondary outcomes, including use of noninvasive ventilation, in-hospital mortality, or duration of hospital stay. ${ }^{7}$ Two relatively large $(n>100)$ RCTs also failed to demonstrate improvement in viral parameters (viral load) or clinical outcomes (hospitalization, mortality, symptom resolution) in nonhospitalized patients treated with HCQ compared to standard of care or placebo. ${ }^{12,13}$

As we turn to 5 small trials from China, we observe a possible suggestion of clinical improvement. An RCT comparing HCQ (400 mg daily) plus standard of care to standard of care alone in 62 COVID-19-positive patients with chest CT confirmation and mild illness (partial pressure arterial oxygen/fraction of inspired oxygen $\left[\mathrm{PaO}_{2} / \mathrm{FiO}_{2}\right]>300$ ) demonstrated a significantly quicker time to clinical recovery (defined as afebrile body temperature and resolution of cough) and improvement in chest CT imaging in the HCQ group. ${ }^{5}$ L. Chen et al corroborated a trend to shorter recovery with $\mathrm{HCQ}$ (200 $\mathrm{mg}$ twice daily) in a small study ( $n=48)$ of HCQ and standard of care vs CQ (500 to 1,000 mg daily) and standard of care vs standard of care. ${ }^{8}$ Only 


\begin{tabular}{|c|c|c|c|c|c|}
\hline \multirow[b]{2}{*}{ Study Characteristic } & \multicolumn{5}{|c|}{ Study and Publication Date } \\
\hline & Borba et al, $2020^{11}$ & Boulware et al, $2020^{6}$ & Cavalcanti et al, 20207 & Chen CP et al, $2020^{10}$ & Chen J et al, $2020^{4}$ \\
\hline Study design & $\begin{array}{l}\text { Double-blind, randomized } \\
\text { controlled }\end{array}$ & $\begin{array}{l}\text { Double-blind, randomized } \\
\text { controlled }\end{array}$ & $\begin{array}{l}\text { Multicenter, open-label, } \\
\text { randomized controlled }\end{array}$ & $\begin{array}{l}\text { Multicenter, open-label, } \\
\text { randomized controlled }\end{array}$ & Randomized controlled \\
\hline $\begin{array}{l}\text { Country/countries of } \\
\text { origin }\end{array}$ & Brazil & United States and Canada & Brazil & Taiwan & China \\
\hline Patient population & $\begin{array}{l}\text { Hospitalized patients } \geq 18 \\
\text { years, clinical suspicion of } \\
\text { COVID- } 19 \text { with } \geq 1 \text { of } \\
\text { respiratory rate }>24 / \mathrm{min}, \\
\text { heart rate }>125 / \mathrm{min}, \mathrm{O}_{2} \\
\text { saturation }<90 \% \text { on room } \\
\text { air, shock }\end{array}$ & $\begin{array}{l}\text { Asymptomatic individuals } \\
\geq 18 \text { years, household or } \\
\text { occupational exposure to } \\
\text { a person with confirmed } \\
\text { COVID- } 19 \text { at }<6 \text { feet for } \\
>10 \text { minutes }\end{array}$ & $\begin{array}{l}\text { Hospitalized patients } \geq 18 \\
\text { years, suspected or } \\
\text { confirmed COVID-19 } \\
\text { within } 14 \text { days of } \\
\text { symptom onset }\end{array}$ & $\begin{array}{l}\text { Patients } 20-79 \text { years, mild or } \\
\text { moderate illness by CXR }\end{array}$ & $\begin{array}{l}\text { Patients } \geq 18 \text { years, } \\
\text { confirmed moderate } \\
\text { COVID-19 disease }\end{array}$ \\
\hline $\begin{array}{l}\text { Method of COVID-19 } \\
\text { testing }\end{array}$ & $\begin{array}{l}\text { RT-PCR (patients were } \\
\text { enrolled before results } \\
\text { returned) }\end{array}$ & $\begin{array}{l}\text { None for study subjects } \\
\text { Contacts initially only } \\
\text { required to have } \\
\text { presumptive COVID-19; } \\
\text { switched to RT-PCR } \\
\text { confirmation during } \\
\text { enrollment }\end{array}$ & RT-PCR & RT-PCR & Not specified \\
\hline Intervention & $\begin{array}{l}\text { High-dose } C Q+\text { standard of } \\
\quad \text { care }(n=81)\end{array}$ & $\mathrm{HCQ}(\mathrm{n}=414)$ & $\begin{array}{l}\mathrm{HCQ}+\text { standard of care } \\
(n=59) \\
\text { HCQ }+ \text { azithromycin }+ \\
\text { standard of care }(n=172)\end{array}$ & $\begin{array}{l}\mathrm{HCQ}+\text { standard of care } \\
\quad(\mathrm{n}=21)\end{array}$ & $\begin{array}{l}\mathrm{HCQ}+\text { standard of care } \\
\quad(\mathrm{n}=15)\end{array}$ \\
\hline $\begin{array}{l}\text { Treatment medication } \\
\text { dose }\end{array}$ & $\begin{array}{l}\text { CQ } 600 \text { mg twice daily for } 10 \\
\text { days } \\
\text { Ceftriaxone } 1 \mathrm{~g} \text { twice daily } \\
\text { for } 7 \text { days } \\
\text { Azithromycin } 500 \text { mg daily } \\
\text { for } 5 \text { days }\end{array}$ & $\begin{array}{l}800 \mathrm{mg} \text { once, then } 600 \mathrm{mg} \\
6-8 \text { hours later, then } 600 \\
\text { mg daily for } 4 \text { days }\end{array}$ & $\begin{array}{l}\text { HCQ } 400 \text { mg twice daily for } 7 \\
\text { days } \\
\text { Azithromycin } 500 \text { mg daily } \\
\text { for } 7 \text { days } \\
+ \text { standard of care }\end{array}$ & $\begin{array}{l}\text { HCQ } 400 \text { mg twice daily on } \\
\text { day } 1 \text {, then } 200 \text { mg twice } \\
\text { daily for } 6 \text { days }+ \\
\text { standard of care }\end{array}$ & $\begin{array}{l}\text { HCQ } 400 \text { mg daily for } 5 \\
\text { days + standard of } \\
\text { care }\end{array}$ \\
\hline Control & $\begin{array}{l}\text { Low-dose CQ + standard of } \\
\quad \text { care }(n=40)\end{array}$ & Placebo $(n=407)$ & Standard of care $(n=173)$ & Standard of care $(n=12)$ & Standard of care $(n=15)$ \\
\hline $\begin{array}{l}\text { Control medication } \\
\text { dose }\end{array}$ & $\begin{array}{l}\text { CQ } 450 \text { mg twice daily on } \\
\text { day } 1 \text {, then } 450 \text { mg daily } \\
\text { for } 4 \text { days } \\
\text { Ceftriaxone } 1 \mathrm{~g} \text { twice daily } \\
\text { for } 7 \text { days } \\
\text { Azithromycin } 500 \text { mg daily } \\
\text { for } 5 \text { days }\end{array}$ & $\mathrm{N} / \mathrm{A}$ & $\begin{array}{l}\text { Not specified; at discretion } \\
\text { of treating physicians } \\
\text { Glucocorticoids, } \\
\text { immunomodulators, } \\
\text { antibiotics, and antivirals } \\
\text { permitted }\end{array}$ & $\begin{array}{l}\text { Ceftriaxone } 2 \mathrm{~g} \text { daily for } 7 \\
\text { days } \pm \text { azithromycin } 500 \\
\mathrm{mg} \text { on day } 1 \text {, then } 250 \mathrm{mg} \\
\text { for } 4 \text { days OR levofloxacin } \\
750 \mathrm{mg} \text { daily for } 5 \text { days OR } \\
\text { levofloxacin } 500 \mathrm{mg} \text { daily } \\
\text { OR moxifloxacin } 400 \mathrm{mg} \\
\text { daily for } 7-14 \text { days }\end{array}$ & $\begin{array}{l}\text { Not specified; included } \\
\text { interferon- } \alpha, \\
\text { umifenovir, lopinavir, } \\
\text { ritonavir, antibiotics }\end{array}$ \\
\hline
\end{tabular}


Table. Continued

\begin{tabular}{|c|c|c|c|c|c|}
\hline \multirow[b]{2}{*}{ Study Characteristic } & \multicolumn{5}{|c|}{ Study and Publication Date } \\
\hline & Borba et al, 202011 & Boulware et al, $2020^{6}$ & Cavalcanti et al, $2020^{7}$ & Chen CP et al, $2020^{10}$ & Chen J et al, $2020^{4}$ \\
\hline Primary endpoints & Mortality by day 28 & $\begin{array}{l}\text { Symptomatic illness with } \\
\text { positive molecular assay } \\
\text { or COVID-19-related } \\
\text { symptoms }\end{array}$ & Clinical status at 15 days & $\begin{array}{l}\text { Time to negative RT-PCR } \\
\text { from randomization until } \\
14 \text { days }\end{array}$ & $\begin{array}{l}\text { Proportion of negative } \\
\text { SARS-CoV-2 } \\
\text { pharyngeal swabs on } \\
\text { day } 7\end{array}$ \\
\hline Secondary endpoints & $\begin{array}{l}\text { Mortality by day } 13 \\
\text { Participant clinical status and } \\
\text { laboratory examinations } \\
\text { ECG on days } 13 \text { and } 28 \\
\text { Duration of supplemental } \\
\text { oxygen and/or } \\
\text { mechanical ventilation } \\
\text { Time from treatment } \\
\text { initiation to death }\end{array}$ & $\begin{array}{l}\text { Hospitalization or death } \\
\text { from COVID-19 } \\
\text { Discontinuation of } \\
\text { intervention for any cause } \\
\text { Symptoms at days } 5 \text { and } 14\end{array}$ & $\begin{array}{l}\text { Clinical status at } 7 \text { days } \\
\text { Intubation within } 15 \text { days } \\
\text { HFNC or noninvasive } \\
\quad \text { ventilation use within } 15 \\
\text { days } \\
\text { Duration of hospital stay } \\
\text { In-hospital mortality } \\
\text { Thromboembolism } \\
\text { AKI } \\
\text { Days alive and free of } \\
\text { respiratory support up to } \\
15 \text { days }\end{array}$ & $\begin{array}{l}\text { Proportion of negative viral } \\
\text { RT-PCR on day } 14 \\
\text { Resolution of clinical } \\
\text { symptoms } \\
\text { Proportion discharged by } \\
\text { day } 14 \\
\text { Mortality rate }\end{array}$ & $\begin{array}{l}\text { Mortality } \\
\text { Time to negative } \\
\text { seroconversion } \\
\text { Time to body } \\
\quad \text { temperature } \\
\quad \text { normalization } \\
\text { Radiologic evidence of } \\
\text { improvement } \\
\text { Safety profile }\end{array}$ \\
\hline Results & $\begin{array}{l}\text { Study stopped after interim } \\
\text { analysis showed increased } \\
\text { incidence of QTc interval } \\
\text { prolongation and lethality } \\
\text { in high-dose CQ group } \\
\text { Because of small sample size, } \\
\text { unable to show any } \\
\text { benefit regarding } \\
\text { treatment efficacy }\end{array}$ & $\begin{array}{l}\text { No significant difference in } \\
\text { development of new } \\
\text { COVID-19 } \\
\text { No mortality }\end{array}$ & $\begin{array}{l}\text { No significant difference in } \\
\text { clinical status at day } 15 \\
\text { No significant difference in } \\
\text { any secondary outcome }\end{array}$ & $\begin{array}{l}\text { No significant difference in } \\
\text { time to negative RT-PCR } \\
\text { No significant difference in } \\
\text { proportion of negative } \\
\text { RT-PCR on day } 14 \\
\text { No mortality in either group }\end{array}$ & $\begin{array}{l}\text { No significant difference } \\
\text { in proportion of } \\
\text { negative testing at } 7 \\
\text { days } \\
\text { No significant difference } \\
\text { in time to negative } \\
\text { seroconversion, time } \\
\text { to body temperature } \\
\text { normalization, or } \\
\text { radiologic } \\
\text { improvement } \\
\text { No mortality }\end{array}$ \\
\hline
\end{tabular}




\begin{tabular}{|c|c|c|c|c|c|}
\hline \multirow[b]{2}{*}{ Study Characteristic } & \multicolumn{5}{|c|}{ Study and Publication Date } \\
\hline & Borba et al, $2020^{11}$ & Boulware et al, $2020^{6}$ & Cavalcanti et al, $2020^{7}$ & Chen CP et al, $2020^{10}$ & Chen J et al, $2020^{4}$ \\
\hline Study limitations & $\begin{array}{l}\text { Small sample size } \\
\text { Single center } \\
\text { No placebo group } \\
\text { No exclusion criteria based } \\
\text { on baseline QTc } \\
\text { No chest CT scans to } \\
\text { evaluate disease severity } \\
\text { More patients with heart } \\
\text { disease assigned to } \\
\text { high-dose vs low-dose } \\
\text { group } \\
\text { High-dose group more } \\
\text { susceptible to cardiac } \\
\text { complications with or } \\
\text { without medication use }\end{array}$ & $\begin{array}{l}\text { Single center } \\
\text { Most subjects were health } \\
\text { care workers } \\
\text { Most subjects unable to } \\
\text { access COVID-19 testing } \\
\text { to confirm infection } \\
\text { Online recruitment led to } \\
\text { generally younger and } \\
\text { healthier research } \\
\text { population (selection } \\
\text { bias) and increased } \\
\text { difficulty of follow-up } \\
\text { Exposure poorly defined } \\
\text { No outcomes based on } \\
\text { imaging or viral load } \\
\text { Moderate adherence }\end{array}$ & $\begin{array}{l}\text { Large range of odds ratios } \\
\text { Unblinded } \\
\text { Protocol deviations related } \\
\text { to lack of medication } \\
\text { Included patients who had } \\
\text { received HCQ and/or } \\
\text { azithromycin before study } \\
\text { enrollment } \\
\text { Included patients up to } 14 \\
\text { days after beginning of } \\
\text { symptoms } \\
\text { Unspecified control group } \\
\text { treatment } \\
\text { No outcomes based on } \\
\text { imaging or viral load } \\
\text { Fewer patients in control } \\
\text { group had serial ECGs } \\
\text { during follow-up }\end{array}$ & $\begin{array}{l}\text { Only included patients with } \\
\text { mild/moderate illness } \\
\text { Small sample size } \\
\text { Younger patient population } \\
\text { (mean } 32.9 \text { years) than } \\
\text { other studies } \\
\text { Three patients } \\
\text { concomitantly } \\
\text { administered } \\
\text { azithromycin } \\
\text { No outcomes based on } \\
\text { imaging }\end{array}$ & $\begin{array}{l}\text { Single center } \\
\text { Only included patients } \\
\text { with moderate disease } \\
\text { No diagnosis } \\
\text { confirmation method } \\
\text { specified } \\
\text { Small sample size } \\
\text { Heterogeneous control } \\
\text { group treatment, } \\
\text { including antivirals and } \\
\text { unspecified antibiotics } \\
\text { No QTc monitoring }\end{array}$ \\
\hline $\begin{array}{l}\text { Medication-related } \\
\text { adverse events }\end{array}$ & $\begin{array}{l}\text { QTc prolongation ( }>500 \mathrm{~ms} \\
\text { with CQ) } \\
\text { Myopathy and } \\
\text { rhabdomyolysis with CQ } \\
\text { Myocarditis related to } \\
\text { SARS-CoV-2 may progress } \\
\text { to arrhythmias with } \\
\text { prolonged QTc }\end{array}$ & $\begin{array}{l}\text { Increased incidence of } \\
\text { adverse events in HCQ } \\
\text { group; most commonly GI } \\
\text { upset, neurologic } \\
\text { symptoms (headache, } \\
\text { vertigo, irritability) } \\
\text { No cardiac arrhythmias or } \\
\text { other serious } \\
\text { complications }\end{array}$ & $\begin{array}{l}\text { Increased incidence of } \\
\text { adverse events in HCQ } \\
\text { group } \\
\text { Increased risk of QTC } \\
\text { prolongation in HCQ } \\
\text { group } \\
\text { Increased risk of } \\
\text { aminotransferase } \\
\text { elevation in HCQ + } \\
\text { azithromycin vs control } \\
\text { groups }\end{array}$ & $\begin{array}{l}\text { HCQ-associated Gl upset, } \\
\text { headache, dizziness } \\
\text { No QTc prolongation } \\
\text { reported }\end{array}$ & $\begin{array}{l}\text { No difference in adverse } \\
\text { events between } \\
\text { groups } \\
\text { Mild diarrhea, muscle } \\
\text { weakness, and ALT } \\
\text { elevations reported in } \\
\text { HCQ group }\end{array}$ \\
\hline
\end{tabular}




\section{Study Characteristic}

Study design

Country/countries of origin

Patient population$$
\text { testing }
$$

Intervention

Treatment medication dose

Control

Control medication

dose

Primary endpoints

Secondary endpoints

\section{Open-label, randomized,} controlled

\section{China}

Patients $18-75$ years, mild or moderate illness

RT-PCR or chest CT

$\mathrm{HCQ}+$ standard of care $(\mathrm{n}=18)$

$\mathrm{CQ}+$ standard of care $(n=18)$

HCQ 200 mg twice daily for 10 days

CQ 1,000 mg on day 1 , then 500 mg daily for 9 days

+ standard of care

Standard of care $(n=12)$

Not specified

Time to clinical recovery

Time to negative RT-PCR Length of hospital stay

Changes on chest $C T$

Duration of supplemental oxygen

Frequency of adverse events

Clinical status

All-cause mortality

Vital signs

Inflammatory marker testing

\section{$\mathrm{HCQ}+$ standard of care}

$$
(\mathrm{n}=31)
$$

HCQ 400 mg daily for 5 days

CQ + standard of care

$$
(n=136)
$$

HCQ $800 \mathrm{mg}$ on day 1 , then $400 \mathrm{mg}$ daily for 6 days

Standard of care $(n=31)$

Not specified; included

antivirals, antibiotics, immunoglobulins, corticosteroids

Time to clinical recovery

Radiologic evidence of improvement

Safety profile

Standard of care $(n=157)$

Not specified

Reduction of viral RNA load on days 3 and 7

Clinical progression resolution of symptoms

Multicenter, open-label,
randomized controlled
Spain
Nonhospitalized patients
$\geq 18$ years, mild
symptoms of COVID-19
RT-PCR

HCQ + standard of care
$(n=136)$
HCQ 800 mg on day 1, then
400 mg daily for 6 days

Placebo $(n=211)$

N/A

Time from randomization to Safety profile symptoms

$$
(n=212)
$$
days and 14 or death

\begin{tabular}{cc}
\hline Skipper et al, 2020 & Tang et al, 2020 \\
\hline $\begin{array}{c}\text { Multicenter, double-blind, } \\
\text { randomized controlled }\end{array}$ & $\begin{array}{c}\text { Multicenter, open-label, } \\
\text { randomized controlled }\end{array}$
\end{tabular}

United States and Canada

Nonhospitalized patients $\geq 18$ years, $<4$ days of COVID-compatible

\section{PCR-confirmed COVID-19 or RT-PCR} exposure to individual with PCR-confirmed COVID-19 within 14 days

$\mathrm{HCQ}+$ standard of care

HCQ 800 mg once, then 600 mg 6-8 hours later, then $600 \mathrm{mg}$ once daily for 4

Clinical outcome at day 14

Symptom severity at days 5

Incidence of hospitalization

Incidence of study medicine withdrawal
$\mathrm{HCQ}+$ standard of care $(n=75)$

HCQ 1,200 mg daily for 3 days followed by 800 mg daily for 2 weeks for mild-moderate disease, 3 weeks for severe disease

Standard of care $(n=75)$

Not specified; according to Chinese national guidelines

Proportion of negative SARS-CoV- 2 by 28 days

Clinical improvement Inflammatory marker levels improvement

Mortality

Adverse events
Radiologic evidence of 


Chen L et al, $2020^{8} \quad$ Chen $Z$ et al, $2020^{5}$

Mitjà et al, $2020^{12}$

\section{Skipper et al, $2020^{13}$}

No significant difference in symptom resolution, hospitalization, or death in CQ group and trend toward shorter recovery in HCQ group

Shorter time to negative RT-PCR in both CQ and HCQ groups

Trend toward decreased

hospitalization length and

improved CT chest changes

in both CQ and HCQ groups

No mortality in any group

No significant difference in

inflammatory markers

Study limitations

\section{Single center}

Unblinded

Only included patients with mild/moderate illness

Small sample size

HCQ dosing based on rheumatoid arthritis treatment

Unspecified control group treatment
Increased improvement

in chest $\mathrm{CT}(80.6 \%$ vs $54.8 \%$ ) in HCQ group HCQ group

vignificant differenc iral RNA load at days 3 or hospitalization or time to symptom resolution

No mortality

\section{Single center}

Only included patients

with mild illness

Small sample size

Heterogeneous control group treatment

Relatively short

observation period

No outcomes based on viral load

No QTC monitoring

\section{Unblinded}

Only included patients with mild illness

Standard of care treatment not specified

No initial plan to evaluate clinical assessments on day 7 , so fewer results than on day 3

High (>80\%) enrollment of health care workers
Medication-related adverse events
Increased incidence of mild adverse events in HCQ and CQ groups, most commonly diarrhea, nausea, ALT/AST elevation

One grade 2 ALT/AST elevation

in $\mathrm{HCQ}$ group

No cardiac adverse events
Two patients in HCQ group with mild adverse events (rash and headache)

No severe adverse events reported
No significant difference in

between treatment

groups

No outcomes based on imaging

No QTc monitoring

Increased incidence of adverse events in $\mathrm{HCQ}$ group (Gl upset, drowsiness, headache, taste change)

No HCQ-related serious adverse events

\section{Tang et al, $2020^{\circ}$}

No significant difference in proportion of negative conversion or speed to negative conversion

No difference in clinical course No difference in inflammatory markers

No mortality reported
Majority of subjects were health care workers

Underrepresentation of Black/African American subjects

Lack of laboratory-confirmed SARS-CoV-2 infection in all participants

Enrollment of patients based on epidemiologic links to known cases

No outcomes based on imaging or viral load Moderate adherence No QTc monitoring

Increased incidence of adverse events in HCQ group (Gl upset)

No serious adverse events attributable to $\mathrm{HCQ}$
Unblinded

High proportion (98\%) of patients with mild/moderate disease

Relatively long lead-in time from symptom onset to treatment ( 16 days)

Premature termination of enrollment for lack of participants

Increased incidence of adverse events in HCQ patients (Gl

upset, blurry vision, increased thirst)

Two serious adverse events in HCQ group (disease progression, upper respiratory tract infection) No cardiac arrhythmias reported

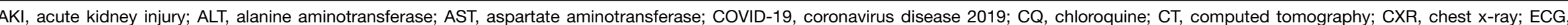

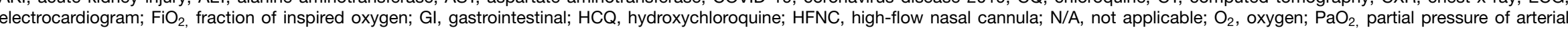

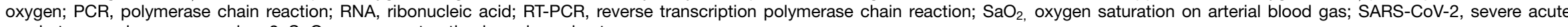


patients with mild or moderate illness (generally patients with oxygen saturation $\left[\mathrm{SaO}_{2}\right]>93 \%$ and/or $\mathrm{PaO}_{2} / \mathrm{FiO}_{2}>300$ ) were enrolled in these 2 studies. Standard of care was based on clinician judgment and was either not specified or varied widely to include antivirals, antibiotics, immunoglobulins, and/or corticosteroids. ${ }^{5,8}$ Thus, the generalizability of such studies to patients with severe COVID-19 who may need more aggressive intervention is questionable.

The 3 other small studies (n ranging from 30 to 150) from China were uniform in identifying a lack of significant difference in proportion or time to negative seroconversion in patients with confirmed COVID-19.4,9,10 Tang et al also observed no difference in clinical course, inflammatory markers, or mortality when HCQ 800 to 1,200 mg/day was added to standard of care therapy. ${ }^{9}$ Similarly, J. Chen et al and C. P. Chen et al observed no difference in mortality or side effects when HCQ 200 to 400 mg/day was added to standard-of-care therapy. ${ }^{4,10}$ These studies also primarily focused on patients with mild or moderate illness.

Turning back to trials outside of China, the potential drawbacks of $\mathrm{HCQ}$ and $\mathrm{CQ}$ regimens emerge. The Borba et al trial terminated prematurely because of the increased incidence of QTc interval prolongation and lethality in a high-dose (600 mg twice daily) CQ group. ${ }^{11}$ Boulware et al observed an increased risk of mild adverse events, including nausea $(22.9 \%$ vs $7.7 \%)$ and diarrhea/abdominal discomfort (23.2\% vs $4.3 \%$ ), in the HCQ treatment group compared to the placebo group, a finding corroborated by the Mitjà et al study. ${ }^{6,12}$ The unblinded Mitjà et al trial had a high enrollment of health care workers ( $86.7 \%$ of study subjects), and $72.0 \%$ of patients taking $\mathrm{HCQ}$ reported adverse events vs $8.7 \%$ of patients in the control arm. ${ }^{6}$ Elevated aminotransferases were also noted as an adverse effect of $\mathrm{HCQ}$ in multiple trials and required discontinuation of the study drug in 1 patient in the J. Chen et al study. ${ }^{4,7,8}$ While these adverse events were mild in many cases, decreased adherence to HCQ compared to placebo was noted in 2 studies of HCQ use in outpatient populations; thus, mild adverse events-especially gastrointestinal symptoms including nausea, abdominal discomfort, and diarrhea-may affect the efficacy of $\mathrm{HCQ}$ treatment for asymptomatic patients or patients with lowacuity cases of COVID-19.,13 Another consideration is that several RCTs specifically excluded patients with preexisting cardiac pathology, underlying QTc interval prolongation, or concomitant use of QTc-prolonging medications, therefore perhaps providing insufficient information about the deleterious cardiac outcomes of $\mathrm{HCQ}$ in the population at large. $6,8,10,12$

Confusion about what role, if any, HCQ should play in COVID-19 treatment is driven in part by significant study limitations, especially in terms of heterogeneous standardof-care treatments and limited external validity. Themes that originated in the first studies from China were small sample sizes and skew of the patient populations to mild and moderate disease..$^{4,5,8-10}$ More concerning from a methodology perspective were the frequent protocol deviations and the lack of placebo groups, control group treatment specifications, and blinding. We have summarized the limitations and challenges with the study designs for these 10 clinical trials in the Table. Ultimately, robust statistical understanding beyond simple $P$ value dichotomy may be necessary to understand the nuances of and draw reasonable conclusions from underpowered trials.

\section{STUDY CHALLENGES DURING A PANDEMIC}

COVID-19 has presented major challenges to the medicalacademic community in terms of conducting clinical trials in an epidemiologically valid yet timely manner. From the studies presented here, we have determined that treatment with HCQ in patients with COVID-19 has not been shown to consistently improve clinical outcomes, although the majority of studies had significant design limitations. HCQ may not become part of the standard treatment for patients with COVID-19, but we can still glean lessons that can inform research in future pandemics. Even in the midst of a rapidly evolving pandemic, potential therapeutics should be rigorously tested. Although avenues for timely data dissemination should exist, the peer review process must continue to be held to a high standard and remain uninfluenced by political or personal conflicts of interest. Standard-of-care treatments used as comparisons should be truly standardized and specified in detail, even in preliminary scientific manuscripts. In addition, patient populations included in early studies must be chosen carefully; discussion of the utility of therapeutics that were only investigated in patients with mild or moderate illness must be heavily tempered when considering their use in patients with more serious disease. Further, the safety profile of novel interventions should be rigorously investigated in the general population. COVID-19 has provided fertile soil for the flourishing of clinical research, but both study designers and the reading audience must take great care to determine how the combined body of research ought to affect clinical care.

\section{ACKNOWLEDGMENTS}

The authors have no financial or proprietary interest in the subject matter of this article.

\section{REFERENCES}

1. Gautret $P$, Lagier JC, Parola $P$, et al. Hydroxychloroquine and azithromycin as a treatment of COVID-19: results of an open-label non-randomized clinical trial. Int J Antimicrob Agents. 2020;56(1):105949. doi: 10.1016/j.jiantimicag.2020.105949

2. Rosendaal FR. Review of: Hydroxychloroquine and azithromycin as a treatment of COVID-19: results of an open-label non-randomized clinical trial Gautret et al 2010, DOI:10.1016/j.ijantimicag.2020.105949. Int J Antimicrob Agents. 2020;56(1):106063. doi: 10.1016/j.ijantimicag.2020.106063

3. Voss A, Coombs G, Unal S, Saginur R, Hsueh PR. Publishing in face of the COVID-19 pandemic. Int J Antimicrob Agents. 2020;56(1):106081. doi: 10.1016/j.ijantimicag.2020.106081

4. Chen J, Liu D, Liu L, et al. A pilot study of hydroxychloroquine in treatment of patients with moderate COVID-19 [in Chinese]. Zhejiang Da Xue Xue Bao Yi Xue Ban. 2020;49(2):215-219.

5. Chen Z, Hu J, Zhang Z, et al. Efficacy of hydroxychloroquine in patients with Covid-19: results of a randomized clinical trial. medRxiv. Preprint posted online April 10, 2020. doi: 10.1101/2020.03.22.20040758

6. Boulware DR, Pullen MF, Bangdiwala AS, et al. A randomized trial of hydroxychloroquine as postexposure prophylaxis for Covid-19. N Engl J Med. 2020;383(6):517-525. doi: 10.1056/NEJMoa2016638 
7. Cavalcanti AB, Zampieri FG, Rosa RG, et al.; Coalition Covid-19 Brazil I Investigators. Hydroxychloroquine with or without azithromycin in mild-to-moderate Covid-19. N Engl J Med. 2020;383(21):2041-2052. doi: 10.1056/NEJMoa2019014

8. Chen L, Zhang Z, Fu J, et al. Efficacy and safety of chloroquine or hydroxychloroquine in moderate type of Covid-19: a prospective open-label randomized study. medRxiv. Preprint posted online June 22, 2020. doi: $10.1101 / 2020.06 .19 .20136093$

9. Tang W, Cao Z, Han M, et al. Hydroxychloroquine in patients mainly with mild to moderate COVID-19: an open-label, randomized, controlled trial. medRxiv. Preprint posted online May 7, 2020. doi: $10.1101 / 2020.04 .10 .20060558$

10. Chen CP, Lin YC, Chen TC, et al. A multicenter, randomized, open-label, controlled trial to evaluate the efficacy and tolerability of hydroxychloroquine and a retrospective study in adults with mild to moderate Coronavirus disease 2019 (COVID-19). medRxiv. Preprint posted online July 10, 2020. doi: 10.1101/2020.07.08.20148841

11. Borba MGS, Val FFA, Sampaio VS, et al.; CloroCovid-19 Team. Effect of high vs low doses of chloroquine diphosphate as adjunctive therapy for patients hospitalized with severe acute respiratory syndrome coronavirus 2 (SARS-CoV-2) infection: a randomized clinical trial. JAMA Netw Open. 2020;3(4):e208857. doi: 10.1001/jamanetworkopen.2020.8857

12. Mitjà $\mathrm{O}$, Corbacho-Monné $\mathrm{M}$, Ubals $\mathrm{M}$, et al.; BCN PEP-CoV-2 Research Group. Hydroxychloroquine for early treatment of adults with mild Covid-19: a randomized-controlled trial. Clin Infect Dis. 2020;ciaa1009. doi: 10.1093/cid/ciaa1009

13. Skipper CP, Pastick KA, Engen NW, et al. Hydroxychloroquine in nonhospitalized adults with early Covid-19: a randomized trial. Ann Intern Med. 2020;173(8):623-631. doi: 10.7326/M20-4207

(C2020 by the author(s); licensee Ochsner Journal, Ochsner Clinic Foundation, New Orleans, LA. This article is an open (c) (1) access article distributed under the terms and conditions of the Creative Commons Attribution (CC BY) license (creativecommons.org/licenses/by/4.0/legalcode) that permits unrestricted use, distribution, and reproduction in any medium, provided the original author(s) and source are credited. 